\title{
Piotr Woltanowski
}

University of Bialystok

e-mail: p.woltanowski@uwb.edu.pl

ORCID: 0000-0002-2154-3587

\section{RISKS OF USING "LANGUAGE RELIEF" AND PLAIN LANGUAGE PRINCIPLES IN THE PROCESS OF APPLYING TAX LAW - SELECTED ISSUES}

\begin{abstract}
The level of communicativeness of official letters in the field of tax law leaves much to be desired. The article concerns the consequences of the application of "Language Relief" in the practice of applying tax law by the National Revenue Administration. The author calls for the principles of plain language to be introduced first in relation to acts of state law, so that officials can adapt their letters to the plain language of the law. A reversal of this order poses significant risks to the protection of taxpayers' rights since internal instructions and letter templates proposed on the NRA intranet will be used to a greater extent instead of legal acts.

Keywords: protection of taxpayers' rights, "Language Relief", plain language, tax letters, National Revenue Administration, application of tax law.
\end{abstract}

It is likewise to be observed, that this society has a peculiar cant and jargon of their own, that no other mortal can understand, and wherein all their laws are written, which they take special care to multiply; whereby they have wholly confounded the very essence of truth and falsehood, of right and wrong...

Jonathan Swift, Gulliver's Travels into Several Remote Nations of the World

\section{Introduction}

It should be emphasised that the clarity of both the acts of law-making and law application is the subject of proposals formulated many times by representatives of the doctrine of financial and tax law. This is of fundamental importance for the protection of taxpayers' rights. Also, both the Constitutional Court (Constitutional Court, 1994) and the Supreme Court (Supreme Court, 1991) have repeatedly expressed in their rulings the con- 


\section{Piotr Woltanowski}

viction of the need to make and apply law, including tax law, in such a way that it does not become a trap for the citizen. Citizens should be able to act in confidence that they will not expose themselves to legal consequences that were unforeseeable at the time the decision was made. (Constitutional Court, 1994) We should agree with the Ombudsman, who, on the basis of the case law of the Constitutional Court, stressed the need to observe three conditions for compliance of the formulation of a specific provision of law with the requirements of correct legislation. These are the following:

1. Precise formulation of the subjective scope of a legal provision and precise determination of factual situations in which subjects are subject to limitations of their constitutional freedoms or rights. When transferring this view to the area of tax law, it should be stated that a provision of the tax law should be formulated in a manner that makes it possible to determine unambiguously who is subject to a given tax and in what situation.

2. A provision should be sufficiently precise to ensure its uniform interpretation and application. In the field of tax law, it is important that the rules are uniformly applied territorially (and not only on the territory of a given Tax Administration Chamber), but also that the rules are uniformly understood by the tax authorities of the first and second instance and the administrative courts.

3. A provision should be formulated in such a way that its scope covers only those situations in which the rational lawmaker actually intended to introduce a regulation limiting the exercise of constitutional freedoms and rights. In the field of tax law, it is important that the provisions of this branch of law should be construed in such a way that their scope of application encompasses only those tax situations in respect of which the rational lawmaker genuinely intended to introduce a tax obligation (Commissioner for Human Rights, 2006).

The Polish Ombudsman has consistently stressed that every taxpayer should be able to learn and understand tax regulations, as this is a prerequisite for the correct application (by the authorities) and implementation (e.g. by taxpayers) of the law and is possible only when the provision of the law is formulated in a transparent (clear), detailed and comprehensible manner (Commissioner for Human Rights, 2006). Otherwise, the actions of the state apparatus will not only contradict the principle of certainty of taxation formulated by Adam Smith, but must also be considered to contradict the constitutional principles of the citizen's trust in the law and in the state (Mastalski, 2011). 
It is worth pointing out here that in the line of jurisprudence initiated by the judgement of 3 December 2002, the Constitutional Court recognised that the ambiguity of a provision may justify the establishment of its inconsistency with the Constitution, if it is so far-reaching that the resulting discrepancies cannot be removed by means of ordinary measures aimed at eliminating the uneven application of the law (Constitutional Court, 2002). Furthermore, the effects of such discrepancies must be significant for the addressees and result from the uneven application of the provision or uncertainty as to the manner of its application. They must affect the legally protected interests of the addressees of the legal norms and be of a certain intensity (Constitutional Court. 2004). It should be noted that inconsistency of application, or uncertainty in this respect, is not the only way in which the text of a legal act that is difficult to understand affects the quality of a legal text, including a letter on tax matters.

In such cases, it seems much more common to rely on all kinds of instructions, circulars, which explain the legal act in a certain way and give the act of applying the law a certain direction. Traces of these instructions can later be seen in the justifications for tax decisions, where they are sometimes "masked" by content taken from non-communicative legal acts. In such a situation, the process of translating taxes into "ordinary language" may be worth starting not with a somewhat haphazard implementation of controversial (and not without errors) tax letter templates related to "Language Relief", but rather with the creation of laws and regulations written in simple yet precise legal language. And only then will we be able to require officials to radically change their language, embedded in a prior change of the laws they apply.

At this point it is necessary to clarify the understanding of the concept of legal language (of which official language is a variant) adopted for the purposes of this article, as the language used in the process of applying the law. A broader understanding of this notion has been adopted, including also the language of legal norms reconstructed from legal regulations by those applying the law.

\section{The principles and essence of "Language Relief" and the determinants of simple language}

Without going into the history of the plain language movement in relation to taxation, which is widely described in other publications (Piekot T., 2013; Petelin R., 2010), I would like to address the current 
state of affairs in Poland, where attempts to apply plain language principles in relation to European funds were followed by their implementation in the National Revenue Administration. In the brochure "Standards of Language Relief in the MF and the NRA", the authors indicate a catalogue of ten principles of "Language Relief" (Ministry of Finance, 2021a; Ministry of Finance 2021b). They call for the following:

1. Focusing on delivering an understandable message to the addressee of the decision (it seems that this point should be expanded to include the need to take into account the fact that for an increasing number of addressees of tax letters, Polish is not the first language).

2. Building a relationship with the recipient by addressing him or her directly, as in an interview (this proposal is difficult to implement in the case of most tax letters).

3. "Guiding the recipient through the text", which can be interpreted, for example, as the need for logical ordering of information in the justification of the decision.

4. The application of the principle "the less the better" in documents understood as limiting oneself to necessary and "informative" information for the recipient. One can discuss here how it relates to the rich jurisprudence on the principle of informing the parties under Art. 9 of the Code of Administrative Procedure and the rules for providing necessary information under Art. $121 \S 2$ of the Tax Ordinance. It should be assumed that it may have a negative impact on the level of protection of the taxpayer's rights.

5. Use of the somewhat incomprehensible principle "one thought should be enclosed in one sentence - thanks to this, the recipient will get acquainted with the content step by step". It seems that in this respect the Polish "Language relief" deviates from the accepted standards of formulating short simple sentences, instead of multiple subordinate complex sentences containing "one thought". Rather, one of the first recommendations should be the need to express the message in short, simple sentences and thus understandable to the recipient (Schriver, J.S., Cheek, A.L., \& Mercer M., 2010).

6. The use of "normal grammar" and writing "as one speaks" is worthy of recommendation (Czerwińska, E., 2013).

7. The avoidance of artificial expressions or phrases not easily understood by the addressee seems to be impossible in the use of legal language. By its very definition, the language of the law is an artificial dialect, created, inter alia, for the purpose of applying the law, expressed in another artificial language - legal language. 
8. The avoidance of the use of the passive voice, participles and impersonal forms, which indicates that the authors based themselves on Englishlanguage literature. It should be noted here that the passive voice is used in everyday Polish much more often than in English.

9. Ensuring clarity of the letter by appropriate highlighting of paragraphs, enumerations, etc. It should be emphasized that the standards in the field of letter formatting and so-called "letter maps" (i.e. their layout) seem to be extremely (I would say excessively) important for the authors of "Language Relief" and occupy a large part of the brochure.

10. Checking, correcting, and improving what seems to be the most accurate of the presented proposals.

These ten principles appear to be somewhat of a carbon copy of corporate guidelines on customer contact principles. In some parts they are written in a puzzlingly incomprehensible language. Nevertheless, the remaining parts are correct. What is particularly worrying here, however, is the fact that such different postulates have been mixed up and presented under the banner of "plain language" (Piekot T., 2013). This could lead to the rejection of the whole idea of improving contact between officials and taxpayers and to the loss of the idea of the principles of plain language.

\section{Sample tax letters drafted in plain language as part of the "Language Relief" project}

An analysis of sample plain language letters presented in early 2021 as model letters to employees of the National Revenue Administration shows that the use of plain language has exacerbated the problem of ambiguity in the text of the letter. Terms recommended for use by officials in their dealings with citizens often have no equivalents in legal acts (in legal language). The proposed simple language (resembling here colloquial language and not legal or official language) does not therefore provide adequate reference to the basis of the demands formulated in the letters. The ranges of meaning of the expressions used in legal and plain language (in the version of "Language relief") do not overlap.

After publication on the intranet under the tab Library of sample letters, the letters "written in simple language, consisting of short, single sentences, in natural syntax" (Ministry of Finance, Tax Collection Department, 2021), raised doubts among NRA employees as to the obligation to use them, and even in some offices these templates were implemented as mandatory (National Section of Tax Administration NSZZ Solidarność, 2021). One of 
them - "template of a request for correction" was subject to detailed criticism by NRA trade unionists. Among the many objections, the following were pointed out:

- grammatical errors,

- stylistic errors,

- errors in the use of capital letters,

- factual errors concerning, inter alia, the unjustified imposition of a fine and the legal basis.

Striving to simplify the message, the authors of the model did not avoid lexical inaccuracies either, suggesting, for example, that the taxpayer can use the services of the postal operator. Under the Postal Law, a distinction should be made between a "postal operator" (i.e. an entrepreneur entitled to provide postal activity on the basis of an entry in the register of postal operators) and the "designated operator" obliged to provide universal services. The addressee of the letter who uses the services of a postal operator other than Poczta Polska (Polish Post) (the operator designated to provide universal services by decision of the President of the Office of Electronic Communications for the period 2016-2025) may, as a result of this mistake in the template, fail to meet a deadline and suffer negative consequences. It is surprising that in a template written in plain language it did not simply mention Poczta Polska (National Section of Tax Administration NSZZ Solidarność, 2021). It seems that (apart from the obvious shortcomings of some templates) the threats arising from the use of plain language in letters concerning tax law result primarily from the following:

- idiomatic expressions used in the language of normative legal and tax acts;

- the legal definitions in legal texts of certain terms, which should not be replaced by more commonly used colloquial terms;

- content-related and syntactic fragmentation of the norms in legal provisions, which exposes the addressee of the message contained in the letter to laborious reconstruction to discover to which provisions the letter refers;

- the presence of vague and imprecise phrases, the replacement of which by apparently close expressions will change the content of the message;

- the use of semantic, lexical, and phraseological neologisms by the legislator.

However, it should be borne in mind that a certain inconsistency (albeit of much lesser intensity than in colloquial language) is unfortunately also a feature of tax documents drafted in legal language (the language of reflection on the legal text). It is often a consequence of a certain carelessness of 
the legislator who creates the legal text. Here, for example, we have the subject of the tax, an important element of the construction of the tax, defined in the literature as the factual or legal state, the occurrence of which the law entails a tax obligation. Often in legal texts and commentaries to them there is a factual presentation of the subject of the tax, according to which, for example, the subject of the real estate tax is the real estate and not, for example, the ownership or possession of land. This may lead to ambiguities (Ruśkowski E., 2000).

\section{"Language relief" and the model of application of tax law by tax authorities}

The application of tax law is most often understood as a decisionmaking process undertaken by an authorised public authority, leading to the issuance of a decision of an individual and specific nature. The model of application of tax law by tax authorities should be qualified as an administrative model. The administrative model of law application is one of the three (next to judicial and managerial) basic types of tax law application. In the literature, it was emphasized that the administrative model differs from the other two by a high level of decision-making leeway resulting from discretion (Morawski L. 2006). However, more recent studies (Kosińska R., Woltanowski P., 2007) attribute this feature to the consequences of a highly unsatisfactory legal state and not to the specificity of the administrative model of law application and associate it with the phenomena of instability of the law, lack of precision of the language of legal acts and, finally, a high degree of complexity of tax law. It is assumed that the administrative model differs from the others in the limited independence of entities applying the tax law. In this respect, they are in a different situation than the courts applying the tax law. The typical features of the administrative model of law application are, for example, all kinds of instructions, strategies, guidelines, official orders and directives that must be followed by tax authorities applying the law in the administrative model (Zieliński M., 2017). The model of application of tax law by tax authorities is supposed to (or should), according to the views expressed in the literature on the subject, include four fundamental successive stages:

1. the determination of the legal basis and interpretative activities involving the construction of a tax norm from legal provisions often found in different acts;

2. the acceptance of a particular state of facts as proven; 


\section{Piotr Woltanowski}

3. the subsumption of proven facts under the applicable legal norm;

4. the determination of the legal consequences of the facts found to be proven on the basis of the established legal norm.

However, it should be emphasised here that the above model described in many publications is not actually applied by the Polish tax authorities and is rather an expression of doctrinal postulates than the result of research conducted on the functioning model of tax law application by tax authorities (Kosińska R., Woltanowski P., 2007).

Ad. 1. The first stage of applying tax law according to the model described in the literature would be to establish the legal basis. When adopting this scheme for the purposes of these considerations, it should be pointed out that the tax authority would be much more prone to making mistakes than other administrative bodies. This results from:

- frequent changes in legal texts in the field of tax law,

- the dispersal of legal provisions across a wide range of different instruments

- the important role played by European legislation in the field of tax law

- the changes that may occur in the construction of a tax (especially the tax subject and the tax object) as a result of the amendment of "nontax" legal regulations.

The literature on the subject emphasizes the need to reconstruct the legal norm "on the basis of a specific legal culture", i.e. constitutional legal principles, principles resulting from the Tax Ordinance, judicial decisions, doctrinal views read from the justifications to draft acts of the legal intentions of the legislator, and/or axiological assumptions of the legal system (Zieliński M., 2017). When interpreting legal provisions, tax authorities should pay particular attention to legal definitions (often placed outside of a provision separated in a legal act, containing most statutory definitions and derived from the texts of "non-tax" acts), idiomatic terms used in the language of legal and tax regulations, norms, the presence of numerous imprecise and vague phrases, and numerous neologisms (Kosińska R., Woltanowski P., 2007). The literature on the subject unequivocally indicates that in the interpretation of the law taking place at this stage, priority should be given to linguistic interpretation, which refers to the basic, direct linguistic meaning of a provision (Zieliński M., 2017). The use of functional and systemic interpretation is recommended in the theoretical model of application of tax law by tax authorities primarily when:

- the meaning of a provision cannot be established by linguistic interpretation, 
- the meaning established through linguistic interpretation is contrary to hierarchically higher norms of the legal system

- the meaning established through linguistic interpretation is contrary to the axiological foundations of the legal system.

Meanwhile, research conducted 14 years ago (Kosińska R., Woltanowski P., 2007) showed that the axiological foundations of the system of law and constitutional principles are hardly used by tax authorities in their daily practice of law application. This situation has not changed in light of the results of the current research. Furthermore, they confirmed the ignorance of legal principles (found in earlier studies) and the lack of skills to interpret the law among some managerial staff (Morawski L. 2006). Another cause for concern in the process of interpreting the law is the use of too many non-legal models - other than case law and statements of doctrine - which still dominate over legal models and are perceived as the easiest to apply, the most relevant and up-to-date (Kosińska R., Woltanowski P., 2007; Drywa A., 2014).

In the literature on the subject, constitutional principles are (or rather should be) invoked at this stage of law application (Mastalski, 2011). These are above all: the principle of citizen's trust in the state derived from the principle of a democratic legal state; the principle of social justice; the principle of equality; the principle of universality of taxation; the principle of access to a fair, quick, and open trial; the principle of protection of personal data; and the principle of two instances of proceedings. On this occasion, the literature also points to the demands expressed in the doctrine regarding the apolitical nature of tax authorities, the ethical neutrality of tax law, and the convenience of taxation. The research did not reveal a wider conscious application of the aforementioned principles and implementation of the indicated doctrinal postulates.

The second stage of application of the law by tax authorities, as described in the doctrine, should boil down to establishing a specific factual situation and should end with acknowledging a specific fact as proven. With regard to tax proceedings, the Tax Ordinance (hereinafter: T.O.) adopts the principle of objective truth, set forth in Article 122 of T.O., and the principle of completeness of evidence, set forth in Article $187 \S 1$ of T.O. It is assumed that at this stage the tax authority collects and examines all the evidence. On the basis of the analysis of this data it may establish the true and exhaustive state of facts. It is believed that the practice of adjudicating (on the basis of evidence which is incomplete, but sufficient to issue a ruling) is incorrect under the provisions of the Ordinance. 


\section{Piotr Woltanowski}

After the facts are established in the theoretical model of application of tax law by the tax authorities, subsumption should take place. Subsumption consists in qualifying a specific established factual state to a category of states of affairs defined by abstract legal norms (or in assigning a factual state to a general legal norm (rule)). Thanks to this, it will be possible to ascribe to them the effects that the law provides for a given category of states. In the practice of the application of tax law, the subordination rather comes down to the establishment of the "similarity" between the state of affairs described by the legal regulations and the assessed state of affairs, considered in such a way that it is possible to determine the desired legal consequences of the established "similarity". The determination of the legal consequences of the facts found to be proven on the basis of the established legal norm should be the consequence of a correctly performed subsumption.

The research shows that this common-sense theoretical model, which is also accepted in the literature as the correct theoretical model for the application of the law by the tax authorities, is not properly implemented in the practice of the tax authorities. In fact, we observe the following stages:

Stage I Determination of the legal consequences that the body issuing the ruling will aim at.

Stage II Appropriate selection of legal regulations, which will be the legal basis for a decision.

Stage III Analysis of the factual situation in terms of indicating elements that match the previously determined legal basis.

Stage IV Settlement.

This incorrect practice has already been described in detail in a study which is the result of our research with Dr. R. Kosińska (Kosińska R., Woltanowski P., 2007). Here I would like to focus on probable and already partly observed changes in this model determined by the need to use simple language. This matter requires further in-depth research, the results of which will be presented shortly. Here it is worth pointing out the most obvious dangers in this respect. First of all, it is the temptation of unreflective use of ready-made letter templates. Their quality has already been presented earlier in this article.

Another danger is the breakdown of communication between the language of the law (the language of the legal act) and legal language (in this case, the language of the clerk). A feature of legal language is the use of terminology taken from legal acts (the language of the law) - this ensures the precision of the legal text and, above all, has a guarantee function to- 
wards the recipients, who receive a message referring to their actual legal situation (Chodun A., Zieliński M., 2013). The use of a different (simpler, in the authors' intention) vocabulary by the language in which a tax ruling will be written than the one used in legal acts will have a very negative impact on the protection of taxpayers' rights. Interviews with NRA staff indicate a tendency (fortunately, still on a small scale) to apply the principles of plain language in correspondence between authorities. It should be stressed that in practice this may significantly reduce the effectiveness of the National Revenue Administration.

\section{Conclusions}

Putting aside all the doubts that the author of this article has about the results of the application of the plain language principles by NRA to date, it should be stated that it may be possible to reconcile precision (and thus secure taxpayers' rights) and plain language. However, a basic catalogue of plain language principles worth applying in the National Revenue Administration should be created.

Moreover, these are additional minor remarks to be concerned about:

1. First and foremost, we should strive to simplify the language of the law - the language of regulations and tax acts, so that it is understandable to people without higher, legal education. This will facilitate the implementation of the law by its addressees. Furthermore, it will reduce the need for non-lawyer officials to use guidelines and instructions. Legislators should remember that the addressees of tax law are not only lawyers, it will greatly facilitate the work of officials and will have a positive impact on the quality of their work.

2. Letters addressed to taxpayers should be accompanied by standard explanatory notes and a glossary of terms. This solution is going to allow for greater standardization of the official language and is much safer than the currently recommended methods. A suitable glossary of terms can be developed by law and language specialists. This is connected with the postulate of greater involvement of lawyers - specialists in interpretation and tax law - in the activities of the Ministry of Finance.

3. Letters should be written in legal language, referring to the conceptual grid of the language of the law. The use of a single conceptual grid is essential for the safety of taxpayers. Minor changes involving the use of more common synonyms may distort the meaning of the instruction contained in the official letter. 


\section{Piotr Woltanowski}

4. Sentences of official letters should be short, avoiding multiple subordinate clauses. This is one of the most adequate, common-sense solutions to the proposed reform of the language in official communication in the aspect of legal regulations.

\section{R E F E R E N C E S}

Chodun, A., Zieliński, M. (2013). Język urzędowy a język urzędników. Precyzja, adekwatność, komunikatywność. In: I Kongres Jezyka Urzędowego. Kancelaria Senatu.

Commissioner for Human Rights (2006), Ombudsman's request of 12 March 2006, ref. no. RPO-489470-VI/04/AB.

Constitutional Court (1994). Ruling of the Constitutional Court of 24 May 1994. ref. K.1/94. Orzecznictwo Trybunału Konstytucyjnego, I, 13, 78.

Constitutional Court (2002). Verdict of the Constitutional Court of 3 December 2002, ref. P 13/02. Orzecznictwo Trybunatu Konstytucyjnego, 7A, 90.

Constitutional Court (2004). Verdict of the Constitutional Court of 25 October 2004, ref. SK 33/03. Orzecznictwo Trybunatu Konstytucyjnego, 9, 94.

Czerwińska, E. (2013). Kultura języka urzędowego. In: I Kongres Języka Urzędowego. Kancelaria Senatu.

Drywa A. (2014), Odpowiedzialność odszkodowawcza za wydanie niezgodnej z prawem decyzji podatkowej. Wolters Kluwer.

Kosińska, R., Woltanowski P. (2007). In: Gilowska, Z., Izdebski, H., Raczkowski K. (Eds.), Teoretyczny model stosowania prawa podatkowego przez organy podatkowe, a jego realizacja w praktyce. Efektywna administracja skarbowa. Ministry of Finance.

Mastalski, R. (2011). Tworzenie $i$ stosowania prawa podatkowego $w$ zgodzie z Konstytucja. In: Lewkowicz, P., Stankiewicz, J., Konstytucyjne uwarunkowania tworzenia $i$ stosowania prawa finansowego $i$ podatkowego. Temida2.

Morawski, L. (2010). Zasady wykładni prawa. TNOIK Toruń.

Ministry of Finance (2021a). Prosty język. Wyzwania w komunikacji zdalnej. https://power.wup-katowice.pl/file/download/691 (access 15.05.2021).

Ministry of Finance (2021b). Standardy ulgi jezzykowej w MF $i$ KAS. Ministry of Finance.

Ministry of Finance, Tax Collection Department (2021), Letter from the Department of Tax Collection dated 14 May 2021, case number SK/95/2021. http://www.skarbowcy.pl/blaster/extarticle.php?show=article\&article_id $=27833($ access 15.05.2021).

National Section of Tax Administration NSZZ Solidarność (2021), Nie musisz stosować wzorów z "ulgi językowej", http://www.skarbowcy.pl/blaster/ext article.php?show $=$ article\&article $i d=27833($ access 15.05 .2021$)$. 
Risks of Using "Language Relief" and Plain Language Principles...

Petelin R. (2010). Considering plain language: Issues and initiatives. Corporate Communications An International Journal, 2 (15).

Piekot, T. (2013). Ruch prostego jezyka - korzyści i zagrożenia (Standard "plain language" jako język przyjazny obywatelom). In: I Kongres Języka Urzędowego. Kancelaria Senatu.

Ruśkowski, E. (2000). Finanse publiczne i prawo finansowe. v. II. KiK Konieczny i Kruszewski. Oddział Polskich Wydawnictw Profesjonalnych.

Schriver, J.S., Cheek, A.L., \& Mercer M. (2010). The research basis of plain language techniques: Implications for establishing standards. The Clarity Journal, 63, 27-29.

Supreme Court (1991). Verdict of the Supreme Court of 26 July 1991 (ref. I PRN $34 / 91)$.

Zieliński, M. (2017). Wykładnia prawa. Zasady - reguły - wskazówki. Wolters Kluwer. 